\title{
PENINGKATAN HASIL BELAJAR SISWA DENGAN MENGGUNAKAN MEDIA GAMBAR BERBASIS KOLASE PADA PEMBELAJARAN TEMATIK DI MADRASAH IBTIDAIYAH PADANGSIDIMPUAN ANGKOLA JULU
}

\author{
Maulana Arafat Lubis \\ Institut Agama Islam Negeri Padangsidimpuan \\ maulanaarafat@iain-padangsidimpuan.ac.id
}

\begin{abstract}
The problem that is found in this research is low learning outcomes of IV grade student in MI Padangsidimpuan Angkola Julu in thematic learning. The problem is caused learning system given by teacher still not fun, so it does not make student desire in following the learning. This research is conducted to improve learning outcome of IV grade student in MI Padangsidimpuan Angkola Julu in following thematic learning in the theme the beauty of diversity in my country, material magnetic force and gravitational force using collage picture media. This is classroom action research that is consisted of two cycles and every cycle consist of four steps, they are (1) planning, (2) implementation, (3) observation, (4) reflection. The technique of data collection uses observation, test, and interview. Data analysis techniques are conducted qualitatively and quantitatively using questionnaire data analysis in the form of percentages (\%) to get the success of image media implementation toward student's learning outcome. Based on the results of teacher's observations using collage picture media that it obtains $85,5 \%$ in the first cycle and $92,5 \%$ in the second cycle. The data shows an increase in teacher's activity in improving student's learning outcomes. Based on observation result, there is increase in student's learning outcome where cycle I gets $60 \%$ and cycle II gets $84 \%$. The average of student's learning outcome gets increase percentage of $24 \%$. Research result can be concluded that the use of collage picture media can improve student's learning outcome on thematic learning.
\end{abstract}

Keywords: Collage picture media; Learning outcome; Thematic learning. 


\section{PENDAHULUAN}

Hasil belajar merupakan indikator dari salah satu kualitas proses pembelajaran. Proses pembelajaran yang baik akan menghasilkan hasil belajar yang baik pula. Sebaliknya, jika proses pembelajaran dilakukan dengan tidak baik, maka hasil belajar yang didapat juga tidak baik. Hasil belajar siswa pada hakikatnya adalah perubahan tingkah laku, dalam pengertian yang luas mencakup nilai sikap, pengetahuan, dan keterampilan.

Menurut Sabri ${ }^{1}$ hasil belajar dapat ditunjukkan dalam berbagai bentuk, seperti kecakapan, kebiasaan, sikap, pengertian, pengetahuan atau apresiasi (penerimaan atau penghargaan). Sudjana ${ }^{2}$ mengemukakan bahwa hasil belajar adalah kemampuan yang dimiliki siswa setelah ia menerima belajarnya. Sedangkan menurut Bloom bahwa hasil belajar mencakup kemampuan kognitif, afektif, dan psikomotorik. Kognitif yang berisi perilaku menekankan aspek intelektual, seperti pengetahuan dan keterampilan berpikir. Afektif yang berisi perilaku-perilaku menekankan aspek perasaan dan emosi, seperti: minat, sikap, apresiasi, dan cara penyesuaian diri. Psikomotor berisi perilaku yang menekankan aspek keterampilan dengan mengikutsertakan gerak tubuh, seperti praktik menanam tumbuhan dan lain-lain. ${ }^{3}$

Kompetensi sikap berkenaan dengan perlakuan dan perasaan yang terdiri dari lima aspek yakni penerimaan, jawaban atau reaksi, penilaian, organisasi dan internalisasi nilai atau pembentukan karakter. Kompetensi pengetahuan berkenaan dengan hasil belajar intelektual. Kompetensi keterampilan berkenaan dengan hasil belajar kemampuan bertindak. Ketiga ranah ini menjadi objek penilaian hasil belajar. Namun dari ketiga kompetensi tersebut, kompetensi pengetahuanlah yang paling banyak dinilai karena berkaitan dengan kemampuan para siswa dalam menguasai isi bahan pelajaran.

Oleh sebab itu, dalam penilaian hasil belajar, peranan tujuan instruksional yang berisi rumusan kemampuan dan tingkah laku yang diinginkan

\footnotetext{
${ }^{1}$ Ahmad Sabri, Strategi Belajar Mengajar \& Micro Teaching (Ciputat: Quatum Teaching, 2010), 32.

${ }^{2}$ Nana Sudjana, Penilaian Hasil Proses Belajar Mengajar (Bandung: PT Remaja Rosdakarya, 2009), 22.

${ }^{3}$ Maulana Arafat Lubis, Pembelajaran PPKn (Teori Pengajaran Abad 21 di SD/MI) (Yogyakarta: Samudra Biru, 2018), 79.
} 
pada diri siswa menjadi unsur yang paling penting dijadikan sebagai alasan dan acuan penilaian. Karena penilaian hasil belajar adalah upaya memberi nilai terhadap kegiatan pembelajaran yang dilakukan oleh siswa dan guru dalam mencapai tujuan pengajaran. Penilaian ini menelaah sejauh mana keefektifan dan efisiensinya dalam mencapai tujuan pengajaran berupa perubahan tingkah laku. Untuk itu salah satu fungsi hasil belajar adalah umpan balik bagi komponen pembelajaran.

Kurikulum 2013 di tingkat sekolah dasar memadukan tujuh mata pelajaran (PPKn, Bahasa Indonesia, IPS, IPA, SBdP, PJOK, Matematika) sehingga dinamakan pembelajaran tematik. Pembelajaran tematik di dalamnya berisikan tema, subtema, dan pembelajaran. Pada pembelajaran tematik di Madrasah Ibtidaiyah (MI), media sangat diperlukan oleh guru dalam pembelajaran karena pada dasarnya media adalah alat yang dapat memudahkan pendidik dalam menjelaskan materi pelajaran.

Pembelajaran tematik membahas tentang kehidupan sehari-hari yang disusun secara sistematis dan didasarkan percobaan maupun pengamatan dilakukan oleh siswa. Selain itu, tematik merupakan pembelajaran terpadu dari 7 mata pelajaran yang sistematis dan tersusun secara teratur, serta berlaku umum yang berupa kumpulan dari hasil observasi dan eksperimen. Sehingga penggunaan media harus bervariasi sesuai dengan tujuan yang ingin dicapai.

Berdasarkan hasil wawancara yang dilakukan kepada guru kelas dan observasi di lokasi penelitian, masalah yang dijumpai tersebut ialah kemampuan siswa dalam memahami pembelajaran tematik dibuktikan dengan KBM pada semester 1 belum mencapai ketuntasan. Dimana jika diakumulasikan, maka jumlah nilai rata-rata yang diperoleh adalah 68. Sementara itu, jika dilihat dari tingkat keberhasilan siswa dalam belajar yang memperoleh nilai KBM adalah 10 siswa dari jumlah siswa keseluruhan 25 siswa. Hasil pengamatan yang dilakukan telah ditemukan kecenderungan guru yang hanya menggunakan metode ceramah dan penugasan, bahkan media yang membantu guru dalam memudahkan transfer materi juga tidak ada digunakan guru. Ini yang membuat semangat belajar siswa menurun dan siswa cenderung pasif yang menyebabkan rendahnya hasil belajar siswa. Karena pada proses pembelajaran hanya guru saja yang berperan aktif, 
sedangkan siswa kurang dilibatkan sehingga interaksi guru dengan siswa tidak terjadi ataupun bila terjadi hanya sesekali saja.

Media gambar bisa memperlancar pemahaman dan memperkuat ingatan. Media gambar dapat pula menumbuhkan minat belajar siswa dan dapat memberikan hubungan antara isi materi pelajaran dengan dunia nyata. ${ }^{4}$ Media gambar memiliki kelebihan, yaitu: (1) Lebih konkrit dan lebih realistis dalam memunculkan pokok masalah, jika dibandingkan dengan bahasa verbal; (2) Gambar dapat mengatasai masalah batasan ruang dan waktu; (3) Media gambar dapat mengatasi keterbatasan mata; (4) Dapat memperjelas suatu masalah, dalam bidang apa saja dan dapat digunakan untuk semua orang tanpa memandang umur.

Kolase merupakan karya seni rupa dua dimensi yang menggunakan bahan bermacam-macam, selama bahan ajar tersebut dapat dipadukan dengan bahan dasar lainnya yang akhirnya dapat menyatu menjadi karya utuh yang dapat mewakili ungkapan estetis orang yang membuatnya. Sehingga dapat dikatakan bahwa bahan apapun yang dapat dirangkum (dikolaborasikan) sehingga menjadi karya seni dua dimensi juga dapat digolongkan/dijadikan bahan kolase. ${ }^{5}$

Menurut Kasim, ${ }^{6}$ kolase adalah menggambar dengan teknik tempelan. Sumanto ${ }^{7}$ menyatakan bahwa bahan yang digunakan untuk membuat media kolase tidak hanya sebatas seperti halnya montase, namun bisa menggunakan beraneka jenis bahan, seperti: (1) Bahan alam, yaitu bahan-bahan yang berasal dari bendabenda alami atau sisa dari makhluk hidup, seperti daun, ranting, kulit telur, bulu ayam, ampas kelapa, kulit batang pisang, kulit salak, dan lain-lain; (2) bahan buatan, yaitu bahan yang terbuat dari benda-benda olahan manusia, seperti kertas, kain, plastik, benang, kapas, dan lain-lain; (3) bahan bekas, yaitu bahan yang berasal dari benda-benda yang sudah tidak terpakai atau pernah digunakan. Misalnya kertas koran, kertas kalender, kain perca, plastik, sendok es krim, serutan kayu, serutan pensil, tutup botol, dan lain-lain.

\footnotetext{
${ }_{5}^{4}$ Azhar Arsyad, Media Pembelajaran (Jakarta: Rajawali Pers, 2010), 91.

5 Andi Tien Palintan and Saria, -Penggunaan Media Kolase Dalam Meningkatkan Kreativitas Anak,\| Jurnal Al-Athfal 1, no. 1 (2018): 1-9, http://jurnal.umpar.ac.id/index.php/athfal/article/view/9/7.

${ }^{6}$ Siti Nurkhasanah, -Kolase Bahan Alam, Jurnal Abadimas Adi Buana 2, no. 2 (2017): 35-40, http://jurnal.unipasby.ac.id/index.php/abadimas/article/view/952/791.

${ }^{7}$ Sumanto, Pendidikan Seni Rupa di Sekolah Dasar (Malang: Fakultas Ilmu Pendidikan Universitas Negeri Malang, 2011).
} 
Diantara media pembelajaran, media gambar adalah media yang paling umum dipakai karena siswa menyukai gambar terlebih lagi jika gambar dibuat dengan menarik, maka akan menambah semangat siswa dalam mengikuti proses pembelajaran. Melalui penggunaan media, siswa tidak akan merasa bosan dan jenuh, karena sebaliknya siswa akan lebih termotivasi dalam belajar. Inilah yang dikatakan betapa berperannya media gambar terhadap hasil belajar siswa.

Berdasarkan beberapa hasil penelitian terdahulu, media gambar juga mampu meningkatkan hasil belajar siswa. Penelitian yang dilakukan oleh Hayati ${ }^{8}$ menjelaskan bahwa penggunaan media gambar mampu meningkatkan hasil belajar siswa, yang mana pada siklus I ketuntasan siswa mencapai 30\%, sedangkan siklus II ketuntasan siswa mencapai 100\% dengan rata-rata nilai 91,0. Penelitian selanjutnya juga dilakukan oleh Handayani ${ }^{9}$ yang menyatakan bahwa adanya peningkatan hasil belajar siswa setelah menggunakan media gambar pada proses pembelajaran di kelas, yaitu pada siklus I sebesar 69,8\% meningkat pada siklus II sebesar 87,5\%. Ini membuktikan bahwa pemanfaatan media gambar dapat meningkatkan hasil belajar. Hasil penelitian Badriah \& Ma'rifah ${ }^{10}$ dan penelitian Ratnaningsih \& Nastiti ${ }^{11}$ juga mengungkapkan bahwa penggunaan media gambar dapat meningkatkan hasil dan motivasi belajar siswa. Penelitian ini bertujuan untuk meningkatkan hasil belajar siswa kelas IV MI Padangsidimpuan Angkola Julu dalam pembelajaran tematik dengan menggunakan media gambar berbasis kolase. Animo dari penelitian ini ialah hasil belajar siswa meningkat dan

\footnotetext{
${ }^{8}$ Syamsiar Hayati, -Upaya Meningkatkan Hasil Belajar Siswa Melalui Media Gambar Pada Pembelajaran Tematik Tema Perkembangbiakan dan Daur Hidup Hewan di Kelas III Sekolah Dasar Negeri 2 Awang Besar Kecamatan Barabai Kabupaten Hulu Sungai Tengah,\| Jurnal Penelitian Tindakan Dan Pendidikan 4, no. 1 (2018): 69, http://rumahjurnal.net/index.php/ptp/article/viewFile/220/173.

${ }^{9}$ Adhita Dwi Handayani, -Penggunaan Media Kartu Gambar dalam Pembelajaran Tematik Pada Tema Pekerjaan Untuk Meningkatkan Hasil Belajar Siswa Sekolah Dasar,I DAR EL-ILMI: Jurnal Studi Keagamaan, Pendidikan dan Humaniora 4, no. 2 (2017): 118-37, http://ejurnal.unisda.ac.id/index.php/dar/article/view/656/366.

${ }^{10}$ Laelatul Badriah and Isna Ma'rifah, -Peningkatan Hasil Belajar Pembelajaran Tematik Melalui Media Gambar Tema Kegemaranku di Kelas II SD Negeri Margoagung Sleman,\| AlBidayah: Jurnal Pendidikan Dasar Islam 7, no. 1 (2015): 17-30, http://digilib.uinsuka.ac.id/25159/3/02. Laelatul Badriah \%26 Isna Ma’rifah - Peningkatkan Hasil Belajar Pembelajaran Tematik Melalui Media Gambar Tema Kegemaranku di Kelas II SD Negeri Margoagung Sleman.pdf.

${ }^{11}$ Sita Ratnaningsih and Genasty Nastiti, -Upaya Meningkatan Motivasi Belajar Siswa Dengan Menggunakan Media Gambar Pada Pembelajaran Tematik di Sekolah Dasar,\| AL IBTIDA: Jurnal Pendidikan Guru MI 5, no. 2 (2018): 275-86, https://doi.org/http://dx.doi.org/ 10.24235/al.ibtida.snj.v5i2.3397.
} 
media gambar mampu diterapkan semaksimal mungkin sebagai media pembelajaran yang dapat dijadikan untuk mendongkrak prestasi belajar siswa.

\section{METODE PENELITIAN}

Penelitian ini menggunakan pendekatan kualitatif dan kuantitatif dengan metode Penelitian Tindakan Kelas (PTK). Rapport ${ }^{12}$ mendefinisikan penelitian tindakan kelas adalah penelitian untuk membantu guru dalam mengatasi secara praktis persoalan yang dihadapi dalam situasi darurat dan membantu pencapaian tujuan ilmu sosial dengan kerjasama dalam kerangka etika yang disepakati bersama.

Selain itu, Arikunto $\mathrm{dkk}^{13}$ mendefinisikan penelitian tindakan kelas sebagai suatu pencermatan terhadap kegiatan belajar berupa sebuah tindakan yang sengaja dimunculkan dan terjadi di kelas secara bersama. Simpulannya ialah penggunaan penelitian tindakan kelas mampu mengubah dan memperbaiki mutu pembelajaran melalui suatu tindakan yang dirancang dan dilaksanakan oleh guru, baik dari segi kurikulum, metode, media, evaluasi, strategi maupun alat bantu pembelajaran.

Penelitian ini dilaksanakan di kelas IV MI Padangsidimpuan Angkola Julu desa Joring Lombang kota Padangsidimpuan Tahun Pelajaran 2019/2020. Jumlah siswa yang akan diteliti sebanyak 25 orang, terdiri dari 13 orang laki-laki dan 12 orang perempuan. Fokus penelitian ini ialah pada pembelajaran tematik di kelas IV semester genap dengan menggunakan media gambar tema indahnya kebersamaan, subtema keberagaman budaya bangsaku, pembelajaran ke-6 dan fokus pembelajaran PPKn (keberagaman suku bangsa, sosial, dan budaya di Indonesia), Bahasa Indonesia (gagasan pokok dan gagasan pendukung), dan PJOK (gerak dasar lokomotor, non lokomotor, dan manipulatif). Penelitian ini memiliki langkah, yaitu: (1) merencanakan tindakan, (2) melakukan tindakan, (3) mengamati, dan (4) merefleksi dalam memperoleh tingkat capaian hasil belajar yang diharapkan, lalu diperbaiki lebih baik lagi dalam melanjutkan tindakan pada siklus berikutnya.

\footnotetext{
${ }^{12}$ Kunandar, Penelitian Tindakan Kelas (Jakarta: PT. Raja Grafindo Persada, 2011), 46.

${ }^{13}$ Arikunto, Suharjono, and Supardi, Penelitian Tindakan Kelas (Jakarta: Bumi Aksara, 2006), 3 .
} 
Teknik pengumpulan data digunakan untuk memperoleh data penelitian sebagai berikut: (1) observasi, kegiatan mengamati proses pembelajaran secara live terkait fokus penelitian; (2) tes, merupakan pertanyaan, latihan yang digunakan untuk mengukur kemampuan yang dimiliki oleh siswa. Pengumpulan data dengan menggunakan tes yang berupa informasi mengenai pengetahuan, dan sikap siswa. Tahap ini dilakukan untuk mengetahui seberapa besar tingkat keberhasilan dari tindakan yang dilakukan; (3) wawancara, dilakukan pada saat tatap muka langsung dengan siswa, untuk mengetahui kesulitan-kesulitan yang dihadapi siswa selama proses pembelajaran. Data dalam penelitian ini dianalisis untuk mengetahui kesimpulan terhadap penggunaan media gambar pada pembelajaran tematik dengan tema indahnya kebersamaan fokus pembelajaran PPKn (keberagaman suku bangsa, sosial, dan budaya di Indonesia), Bahasa Indonesia (gagasan pokok dan gagasan pendukung), dan PJOK (gerak dasar lokomotor, non lokomotor, dan manipulatif)untuk melihat hasil belajardan masalah-masalah yang dihadapi siswa dalam penggunaan mediagambar.

Kemudian data hasil penelitian dianalisis secara kualitatif dan kuantitatif dengan menggunakan analisis data angket yang dinyatakan dalam bentuk persentase $(\%)$, untuk melihat keberhasilan penggunaan media gambar dalam rangka meningkatkan hasil belajar siswa. Selanjutnya pada pengolahan seluruh data, siswa dikatakan telah tuntas belajar jika siswa tersebut mencapai skor $75 \%$ atau nilai 75. Suatu kelas dikatakan tuntas belajar jika di dalam kelas terdapat $80 \%$. Berikut rumus yang digunakan $\mathrm{DS}=-\mathrm{x} 100 \%$, dimana $\mathrm{DS}=$ Daya Serap, $\mathrm{A}$ $=$ Skor yang telah diperoleh siswa, $\mathrm{B}=$ Skor maksimal. Kriteria bahwa $0 \% \leq \mathrm{DS}<$ $70 \%$ dalam arti siswa belum tuntas dalam belajar dan $75 \% \geq \mathrm{DS} \leq 100 \%$ dalam arti siswa telah tuntas dalam belajar. Selanjutnya dapat juga diketahui bahwa ketuntasan belajar klasikal tercapai dapat dilihat dari persentase siswa yang sudah tuntas dalam belajar dengan rumus $\Sigma$ $\mathrm{P}=$ Persentase ketuntasan klasikal. ${ }^{14}$ Dalam penelitian ini, hasil belajar dikatakan meningkat apabila persentase ketuntasan individual klasikal yang diperoleh siswa semakin meningkat dari tes awal yang diberikan sampai pada tes yang dilakukan

\footnotetext{
${ }^{14}$ Zainal Aqib, Penelitian Tindakan Kelas (Bandung: Yrama Widya, 2008), 41.
} 
setiap siklusnya sekurang-kurangnya $80 \%$ siswa memperoleh nilai tes $>75$. Hasil akhir akan dianalisis dan diinterpretasikan dengan membandingkan skor maupun perlakuan terhadap siklus I dan siklus II.

\section{HASIL DAN PEMBAHASAN}

\section{Hasil Penelitian}

Berdasarkan hasil wawancara dengan guru kelas yang bertujuan untuk mengetahui kondisi awal siswa terhadap mata pelajaran PPKn (keberagaman suku bangsa, sosial, dan budaya di Indonesia), Bahasa Indonesia (gagasan pokok dan gagasan pendukung), dan PJOK (gerak dasar lokomotor, non lokomotor, dan manipulatif) pada tema indahnya kebersamaan dalam pembelajaran tematik. Ternyata dari hasil wawancara yang dilakukan, siswa kurang mampu memahami materi serta menyelesaikan soal-soal yang berhubungan dengan fokus pembelajaran tersebut. Hal ini diketahui dari rendahnya nilai atau skor ujian yang diperoleh siswa pada tahun pelajaran sebelumnya.

Adapun langkah selanjutnya peneliti memberikan tes kepada siswa sebelum melakukan perencanaan bertujuan untuk mengetahui kemampuan siswa dalam menyelesaikan soal-soal yang berkaitan dengan mata pelajaran PPKn (keberagaman suku bangsa, sosial, dan budaya di Indonesia), Bahasa Indonesia (gagasan pokok dan gagasan pendukung), dan PJOK (gerak dasar lokomotor, non lokomotor, dan manipulatif). Maka dari itu hasil belajar siswa pada pretest menggambarkan kemampuan awal siswa dalam menguasai materi dengan nilai rata-rata kelas mencapai 47. Dari 25 siswa terdapat 19 siswa (76\%) yang hasil belajarnya rendah (belum tuntas) dan 6 siswa (24\%) masuk dalam kategori tuntas belajar. Oleh karena itu, data hasil belajar pada pretest digunakan sebagai titik acuan untuk melakukan tindakan pada siklus I dengan maksud untuk mengatasi kesulitan-kesulitan yang dihadapi dalam penyelesaian soal-soal pada mata pelajaran PPKn (keberagaman suku bangsa, sosial, dan budaya di Indonesia), Bahasa Indonesia (gagasan pokok dan gagasan pendukung), dan PJOK (gerak dasar lokomotor, non lokomotor, dan manipulatif).

Hasil belajar tematik siswa sudah mengalami peningkatan, hal ini terlihat dari adanya peningkatan jumlah siswa yang tuntas dalam belajar. Hasil belajar 
siswa siklus I jumlah siswa yang mengalami ketuntasan belajar secara klasikal sebanyak 15 siswa $(60 \%)$ dan jumlah siswa yang belum tuntas belajar secara klasikal sebanyak 10 siswa (40\%), sedangkan hasil belajar siswa siklus II mengalami ketuntasan belajar secara klasikal meningkat menjadi 21 siswa (84\%) dan siswa yang belum tuntas belajar sebanyak 4 siswa (26\%). Jadi, dapat disimpulkan bahwa persentase tingkat ketuntasan secara klasikal mengalami peningkatan sebesar $24 \%$ (dengan jumlah siswa yang telah tuntas belajar secara individual bertambah sebanyak 6 siswa).

Untuk lebih jelasnya dalam melihat tingkat ketuntasan pretest, posttest pada siklus I dan siklus II tentang peningkatan hasil belajar siswa dapat dilihat pada gambar 1 . sebagai berikut.

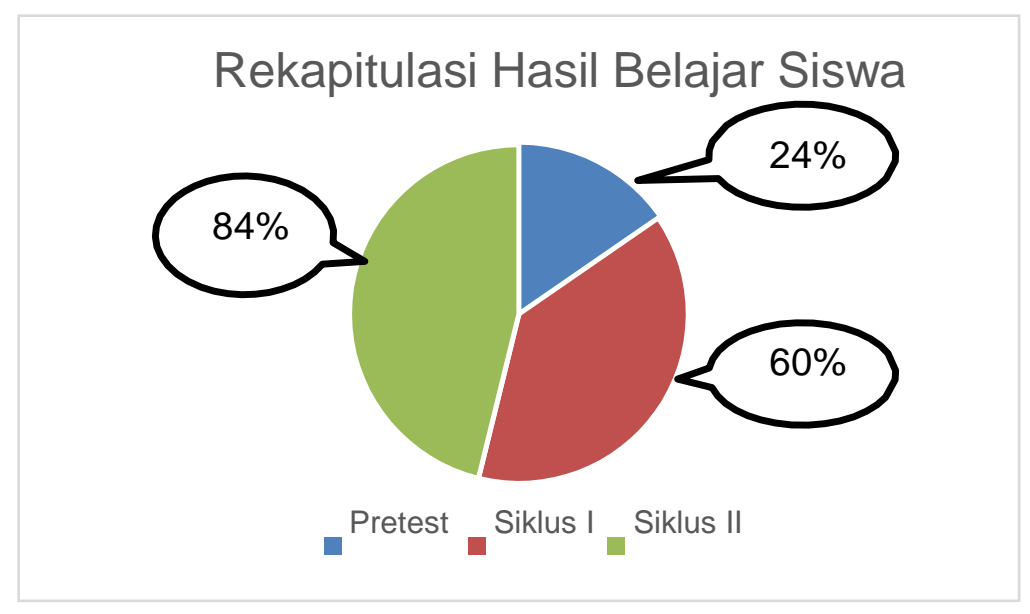

\section{Gambar 1. Rekapitulasi Hasil Belajar Siswa}

Berdasarkan diagram di atas terlihat bahwa persentase rekapitulasi hasil belajar siswa dalam proses pembelajaran tematik tema indahnya kebersamaan mata pelajaran PPKn (keberagaman suku bangsa, sosial, dan budaya di Indonesia), Bahasa Indonesia (gagasan pokok dan gagasan pendukung), dan PJOK (gerak dasar lokomotor, non lokomotor, dan manipulatif) menggunakan media gambar kelas IV pada siklus pretest diperoleh persentase $24 \%$, pada siklus I diperoleh persentase $60 \%$, dan siklus II 84\%. Maka dapat disimpulkan bahwa pada siklus hasil belajar siswa pada pembelajaran tematik fokus mata pelajaran PPKn (keberagaman suku bangsa, sosial, dan budaya di Indonesia), Bahasa Indonesia (gagasan pokok dan gagasan pendukung), dan PJOK (gerak dasar lokomotor, non lokomotor, dan manipulatif) dengan menggunakan media gambar 
berlangsung dan termasuk kategori sangat baik, artinya pada saat proses pembelajaran dengan menggunakan media pembelajaran berupa gambar dapat digunakan dan mampu meningkatkan hasil belajar siswa.

Adapun data hasil observasi aktivitas guru pada siklus I dan siklus II dapat dilihat pada gambar 2. sebagai berikut.

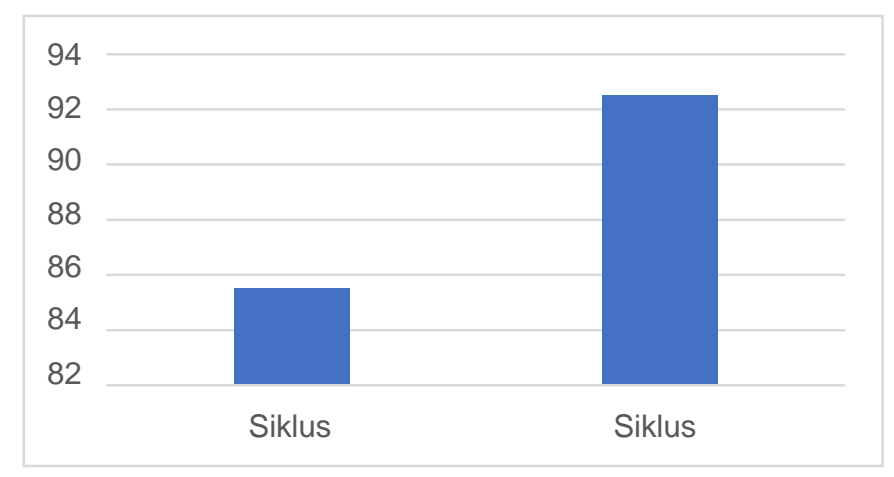

\section{Gambar 2. Rekapitulasi Hasil Observasi Aktivitas Guru}

Berdasarkan gambar 2. di atas terlihat bahwa hasil rekap observasi aktivitas siswa pada siklus I sebesar $85,5 \%$ dan siklus II diperoleh persentase sebesar 92,5\% dengan kategori sangat baik. Hal ini berarti bahwa siswa sudah berperan aktif dalam proses pembelajaran tematik menggunakan media gambar. Maka dapat disimpulkan bahwa pada siklus aktivitas siswa dalam pembelajaran tematik dengan menggunakan media gambar berlangsung dengan sangat baik.

Adapun hasil perolehan aktivitas belajar siswa pada pembelajaran tematik menggunakan media gambar terdapat pada gambar 3 sebagai berikut.

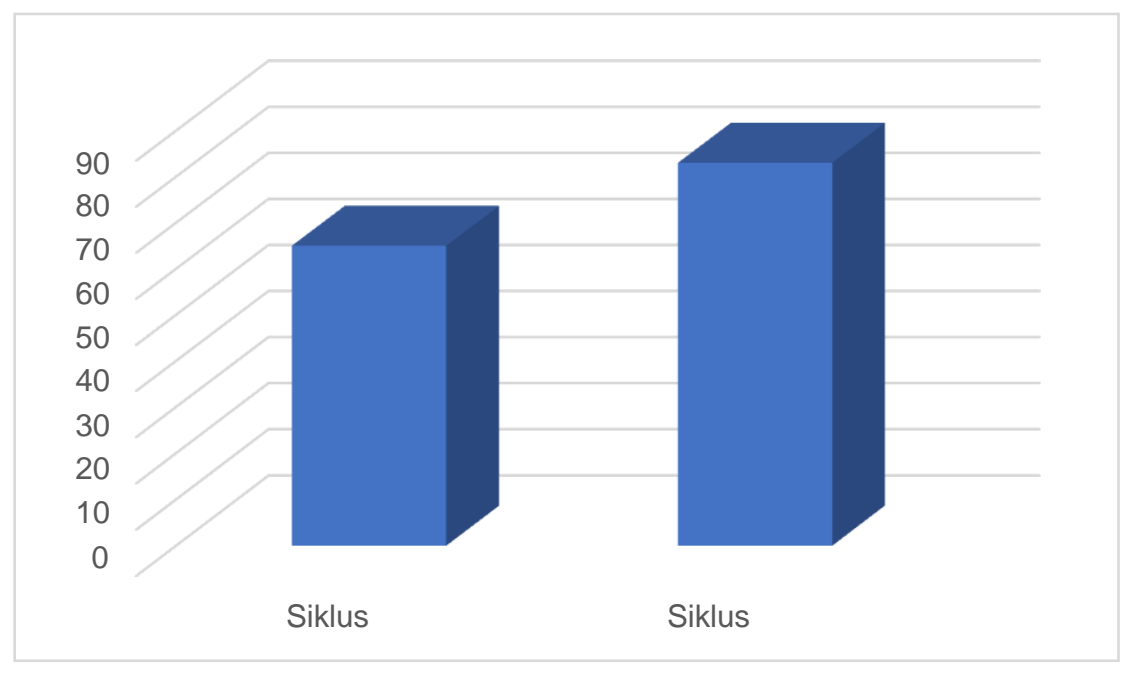

Gambar 3. Rekapitulasi Hasil Observasi Aktivitas Siswa 
Berdasarkan gambar 3 di atas, hasil observasi aktivitas siswa pada siklus I diperoleh sebesar $65 \%$ dan siklus II sebesar $83 \%$, terlihat ada peningkatan dan berada pada kategori baik. Berarti siswa sudah berperaan aktif dalam proses pembelajaran tematik dengan menggunakan media gambar. Adapun rekapitulasi hasil observasi aktivitas guru dan siswa dalam pembelajaran tematik fokus mata pelajaran PPKn (keberagaman suku bangsa, sosial, dan budaya di Indonesia), Bahasa Indonesia (gagasan pokok dan gagasan pendukung), dan PJOK (gerak dasar lokomotor, non lokomotor, dan manipulatif) dengan menggunakan media gambar pada tabel 1 berikut.

Tabel 1. Hasil Belajar Siswa

\begin{tabular}{|l|l|c|c|}
\hline No. & \multicolumn{1}{|c|}{ Hasil Proses Pembelajaran } & Siklus I (\%) & Siklus II (\%) \\
\hline 1. & Hasil observasi aktivitas guru & $85,5 \%$ & $92,5 \%$ \\
\hline 2. & $\begin{array}{l}\text { Hasil observasi aktivitas belajar } \\
\text { siswa }\end{array}$ & $65 \%$ & $83 \%$ \\
\hline \multicolumn{2}{|l|}{ Rata-rata } & $75,2 \%$ & $87,7 \%$ \\
\hline
\end{tabular}

Pada tabel 1 terlihat bahwa hasil observasi aktivitas guru pada siklus I diperoleh sebesar 85,5\% dan pada siklus II diperoleh sebesar 92,5\%. Hal tersebut melihatkan adanya peningkatan aktivitas guru dalam meningkatkan hasil belajar siswa dalam pembelajaran tematik fokus mata pelajaran PPKn (keberagaman suku bangsa, sosial, dan budaya di Indonesia), Bahasa Indonesia (gagasan pokok dan gagasan pendukung), dan PJOK (gerak dasar lokomotor, non lokomotor, dan manipulatif) sebesar 7\%. Sementara itu, hasil observasi aktivitas belajar siswa untuk mengukur hasil belajar siswa dari siklus I yang memperoleh $65 \%$ menjadi $83 \%$ pada siklus II. Hal ini berarti terjadi peningkatan rata-rata hasil belajar siswa dari siklus I ke siklus II sebesar $18 \%$.

\section{Pembahasan}

Pada hakikatnya hasil belajar menjadi tujuan utama siswa dengan mengharapkan nilai yang maksimal dalam proses pembelajaran. Untuk itu guru perlu menerapkan metode beserta media pembelajaran yang menyenangkan 
sehingga siswa mampu menyerap ilmu pengetahuan. Menurut Purwanto ${ }^{15}$ hasil belajar merupakan perubahan perilaku siswa akibat belajar. Selain itu, Mona ${ }^{16}$ juga menyatakan bahwa hasil belajar adalah kemampuan yang dimiliki siswa setelah ia menerima pengalaman belajarnya. Maka dapat disimpulkan bahwa setiap proses pasti membutuhkan hasil, artinya hasil belajar sangat menentukan tercapai atau tidaknya pembelajaran. Adapun pengaruh yang menjadikan hasil belajar menjadi meningkat salah satunya adalah pembelajaran dengan menggunakan media gambar seperti yang dilakukan dalam penelitian ini.

Penelitian ini memfokuskan peningkatan hasil belajar siswa dengan menggunakan media gambar pada pembelajaran tematik tema indahnya kebersamaan mata pelajaran PPKn (keberagaman suku bangsa, sosial, dan budaya di Indonesia), Bahasa Indonesia (gagasan pokok dan gagasan pendukung), dan PJOK (gerak dasar lokomotor, non lokomotor, dan manipulatif) kelas IV MI Padangsidimpuan Angkola Julu. Berdasarkan analisis data kegiatan selama proses pembelajaran berlangsung yang dimulai dari siklus I dengan menggunakan media gambar, maka terlihat adanya peningkatan hasil belajar siswa dengan terlihatnya rata-rata hasil observasi aktivitas guru siklus I sebesar 85,5\%. Namun hasil observasi aktivitas guru masih belum menunjukkan nilai yang maksimal. Maka perlu dilakukan siklus II dengan tujuan untuk memperbaiki kekurangan yang terdapat disiklus I. Kemudian pada siklus II hasil observasi aktivitas guru pada pembelajaran dengan menggunakan media gambar mencapai persentase yang maksimal sebesar $92,5 \%$.

Dari hasil tes diperoleh kemampuan awal siswa masih sangat rendah dengan nilai rata-rata secara keseluruhan 47 dengan siswa yang belum tuntas adalah 19 siswa dengan persentase $76 \%$ dan yang tuntas hanya 6 siswa dengan persentase $24 \%$. Sedangkan ketuntasan secara klasikal adalah $24 \%$ atau berdasarkan kriteria minimal dinyatakan belum tuntas.

Kemudian, untuk meningkatkan hasil belajar siswa pada fokus mata pelajaran PPKn (keberagaman suku bangsa, sosial, dan budaya di Indonesia),

\footnotetext{
${ }^{15}$ Purwanto, Evaluasi Hasil Belajar (Surakarta: Pustaka Pelajar, 2011), 42-43.

16 Maulana Arafat Lubis, -Pengembangan Bahan Ajar Komik Berbasis Model Problem Based Learning Untuk Meningkatkan Hasil Belajar PKn Siswa Kelas V MIN Medan Sunggal\| (Universitas Negeri Medan, 2016), 11, http://digilib.unimed.ac.id/\%0Aid/eprint/8270.
} 
Bahasa Indonesia (gagasan pokok dan gagasan pendukung), dan PJOK (gerak dasar lokomotor, non lokomotor, dan manipulatif)diterapkan dengan menggunakan media gambar. Pada pelaksanaan siklus I hasil belajar diperoleh nilai rata-rata secara keseluruhan adalah 68,6. Siswa yang dinyatakan tuntas belajar yakni 15 siswa dengan persentase 60\%dan yang belum tuntas terdapat 10 siswa denganpersentase $40 \%$. Sedangkan untuk ketuntasan belajar pada siklus Isecara keseluruhan sebesar $60 \%$ sehingga masih belum sesuai dengan kriteria ketuntasan belajar klasikal yang diterapkan (dikatakan tuntas apabila mencapai $80 \%$ yang telah mencapai daya serap $>75$ ). Berdasarkan hasil perhitungan ratarata penilaian setiap indikator yang diamati pada aktivitas mengajar guru pada siklus I berada pada persentase $85,5 \%$ dengan kategori baik. Hal ini menunjukkan bahwa peneliti sudah mampu dalam mengajar dengan menggunakan media gambar pada pembelajaran tematik. Berdasarkan hasil pengamatan terhadap respon belajar siswa terlihat siswa sudah mulai aktif dalam pembelajaran walaupun untuk kegiatan bertanya dan menjawab pertanyaan dari guru masih banyak siswa yang tidak berani bertanya dan menjawab pertanyaan dari guru.

Selanjutnya tindakan kembali dilakukan pada siklus II dan dari tes hasil belajar diperoleh nilai rata-rata siswa secara keseluruhan menjadi 82. Siswa yang dinyatakan tuntas belajar adalah 21 siswa dengan persentase $84 \%$ dan yang belum tuntas terdapat 4 siswa dengan persentase $26 \%$. Tingkat ketuntasan belajar secara klasikal sebesar 84\%. Jadi, dapat disimpulkan bahwa pembelajaran pada siklus II mengalami peningkatan dan telah mencapai ketuntasan belajar secara klasikal. Hal tersebut dapat terjadi karena pada siklus II ini peneliti lebih menggali pengetahuan siswa dan pada siklus II ini siswa tidak lagi belajar kelompok tetapi sendiri-sendiri yang membuat siswa menjadi lebih paham dan menguasai materi dengan menggunakan media gambar. Guru juga sudah melibatkan siswa secara aktif dalam proses pembelajaran dengan menggunakan media gambar, menggunakan waktu secara efektif dan efisien, mengaitkan materi dengan pengetahuan lainnya serta dapat memfokuskan siswa dalam memahami sebuah gambar.

Kemudian di siklus II telah mencapai ketuntasan belajar secara klasikal, maka peneliti berhenti pada siklus II dan tindak melanjutkan kepada siklus III. 
Hal ini menunjukkan bahwa pembelajaran dengan menggunakan media gambar dapat meningkatkan hasil belajar. Artinya, proses pembelajaran dengan menerapkan media gambar pada pembelajaran tematik fokus mata pelajaran PPKn (keberagaman suku bangsa, sosial, dan budaya di Indonesia), Bahasa Indonesia (gagasan pokok dan gagasan pendukung), dan PJOK (gerak dasar lokomotor, non lokomotor, dan manipulatif) dapat meningkatkan hasil belajar siswa kelas IV MI Padangsidimpuan Angkola Julu.

\section{PENUTUP}

Berdasarkan hasil penelitian yang telah dilakukan selama dua siklus yang terdiri dari 3 pertemuan. Mengenai penggunaan media gambar pada pembelajaran tematik kelas IV MI Padangsidimpuan Angkola Julu terlihat bahwa adanya peningkatan hasil belajar siswa. Hasil terlihat berdasarkan observasi pada pembelajaran pra tindakan dengan menggunakan pretest dapat dilihat bahwa hasil belajar siswa masih rendah sebelum menggunakan media gambar. Hal ini terlihat pada tingkat ketuntasan hasil belajar siswa secara klasikal yang belum tuntas belajar sebanyak 19 siswa dengan persentase $76 \%$ dan yang tuntas belajar hanya sebanyak 6 siswa dengan persentase 24\% dan dengan rata-rata kelas sebesar 47 .

Kemudian adanya peningkatan hasil belajar siswa dengan menggunakan media gambar. Siklus I jumlah siswa yang mengalami ketuntasan belajar secara klasikal sebanyak 15 siswa dengan persentase60\%dan jumlah siswa yang belum tuntas belajar secara klasikal sebanyak 10 siswa dengan persentase $40 \%$ dengan nilai rata-rata kelas sebesar 68,6 Sedangkan pada tes hasil belajar siswa siklus II jumlah siswa yang mengalami ketuntasan belajar secara klasikal dan individual meningkat menjadi 21 siswa dengan persentase $84 \%$ dan siswa yang belum tuntas belajar sebanyak 4 siswa dengan persentase $26 \%$ dengan nilai rata-rata kelas sebesar 82 .

Selanjutnya, selama proses pembelajaran dengan menggunakan media gambar respon siswa terus mengalami peningkatan. Siswa menjadi lebih aktif dan rasa ingin tahu siswa menjadi besar. Sehingga suasana dalam proses pembelajaran jadi lebih hidup dan dengan menggunakan media gambar ini pula hasil belajar siswa jadi lebih meningkat. Respon guru terhadap penggunaan media gambar 
pada pembelajaran tematik fokus pembelajaran PPKn (keberagaman suku bangsa, sosial, dan budaya di Indonesia), Bahasa Indonesia (gagasan pokok dan gagasan pendukung), dan PJOK (gerak dasar lokomotor, non lokomotor, dan manipulatif) sangat baik. Sebab, dengan menggunakan media gambar hasil belajar siswa dapat meningkat dan siswa lebih mudah memahami pelajaran sehingga dapat terlihat antusias selama proses pembelajaran.

\section{DAFTAR PUSTAKA}

Aqib, Zainal. Penelitian Tindakan Kelas. Bandung: Yrama Widya, 2008.

Arikunto, Suharjono, and Supardi. Penelitian Tindakan Kelas. Jakarta: Bumi Aksara, 2006.

Arsyad, Azhar. Media Pembelajaran. Jakarta: Rajawali Pers, 2010.

Badriah, Laelatul, and Isna Ma'rifah. -Peningkatan Hasil Belajar Pembelajaran Tematik Melalui Media Gambar Tema Kegemaranku di Kelas II SD Negeri Margoagung Sleman.ll Al-Bidayah: Jurnal Pendidikan Dasar Islam 7, no. 1 (2015): 17-30. http://digilib.uin-suka.ac.id/25159/3/02. Laelatul Badriah \%26 Isna Ma'rifah - Peningkatkan Hasil Belajar Pembelajaran Tematik Melalui Media Gambar Tema Kegemaranku di Kelas II SD Negeri Margoagung Sleman.pdf.

Handayani, Adhita Dwi. -Penggunaan Media Kartu Gambar dalam Pembelajaran Tematik Pada Tema Pekerjaan Untuk Meningkatkan Hasil Belajar Siswa Sekolah Dasar.l DAR EL-ILMI: Jurnal Studi Keagamaan, Pendidikan dan Humaniora 4, no. 2 (2017): 118-37. http://ejurnal.unisda.ac.id/index.php/dar/article/view/656/366.

Hayati, Syamsiar. -Upaya Meningkatkan Hasil Belajar Siswa Melalui Media Gambar Pada Pembelajaran Tematik Tema Perkembangbiakan dan Daur Hidup Hewan di Kelas III Sekolah Dasar Negeri 2 Awang Besar Kecamatan Barabai Kabupaten Hulu Sungai Tengah.l Jurnal Penelitian Tindakan Dan $\begin{array}{lllll}\text { Pendidikan } & 4, & \text { no. } & 1 & \text { (2018): }\end{array}$ http://rumahjurnal.net/index.php/ptp/article/viewFile/220/173.

Kunandar. Penelitian Tindakan Kelas. Jakarta: PT. Raja Grafindo Persada, 2011.

Lubis, Maulana Arafat. Pembelajaran PPKn (Teori Pengajaran Abad 21 di SD/MI). Yogyakarta: Samudra Biru, 2018.

- - - Pengembangan Bahan Ajar Komik Berbasis Model Problem Based Learning Untuk Meningkatkan Hasil Belajar PKn Siswa Kelas V MIN Medan Sunggal.॥ Universitas Negeri Medan, 2016. 
http://digilib.unimed.ac.id/\%0Aid/eprint/8270.

Nurkhasanah, Siti. -Kolase Bahan Alam.l Jurnal Abadimas Adi Buana 2, no. 2 (2017):

http://jurnal.unipasby.ac.id/index.php/abadimas/article/view/952/791.

Palintan, Andi Tien, and Saria. -Penggunaan Media Kolase dalam Meningkatkan Kreativitas Anak.l Jurnal Al-Athfal 1, no. 1 (2018): 1-9. http://jurnal.umpar.ac.id/index.php/athfal/article/view/9/7.

Purwanto. Evaluasi Hasil Belajar. Surakarta: Pustaka Pelajar, 2011.

Ratnaningsih, Sita, and Genasty Nastiti. -Upaya Meningkatan Motivasi Belajar Siswa Dengan Menggunakan Media Gambar Pada Pembelajaran Tematik di Sekolah Dasar.l AL IBTIDA: Jurnal Pendidikan Guru MI 5, no. 2 (2018): 275-86. https://doi.org/http://dx.doi.org/ 10.24235/al.ibtida.snj.v5i2.3397.

Sabri, Ahmad. Strategi Belajar Mengajar \& Micro Teaching. Ciputat: Quatum Teaching, 2010.

Sudjana, Nana. Penilaian Hasil Proses Belajar Mengajar. Bandung: PT Remaja Rosdakarya, 2009.

Sumanto. Pendidikan Seni Rupa di Sekolah Dasar. Malang: Fakultas Ilmu Pendidikan Universitas Negeri Malang, 2011. 